\title{
Structure and petrology of the Dadeldhura Group, far western Nepal, Himalaya
}

\author{
Tomas Næraa $^{1,2}$, Jens Konnerup-Madsen², Bjørn Hageskov ${ }^{2}$, and Lalu Prasad PaudeP \\ ${ }^{1}$ Geological Museum, Copenhagen University \\ ${ }^{2}$ Geological Institute, Copenhagen University \\ ${ }^{3}$ Central Department of Geology, Tribhuvan University, Kirtipur, Kathmandu, Nepal
}

\begin{abstract}
The granites, phyllites, schists, and gneisses of the Dadeldhura Group exhibit a significant Himalayan metamorphic imprint. The rocks of the group constitute a synform and the group is delimited by thrusts. The North Dadeldhura Thrust (NDT) zone is dominated by granitic mylonite with subordinate quartzite, quartz-chlorite schist, and amphibolite. In the quartz-chlorite schist from the NDT zone, relict kyanite is observed, which together with recrystallisation textures in the granitic mylonite indicate that low-temperature syn-tectonic retrogression has affected the thrust zone. Prograde garnets with spiral structures from a zone $2-4 \mathrm{~km}$ structurally above the base of the NDT are associated with mylonite-like rocks, and indicate distinct prograde shear zones in this area. This suggested that prograde thrust stacking has affected about $4 \mathrm{~km}$ wide north belt of the Dadeldhura Group. Rim thermobarometry from the garnet holding rocks shows that the minerals were re-equilibrated at $440-550{ }^{\circ} \mathrm{C}$ and 6.5-9.5 kbar. In the southern part of the Dadeldhura Group, textures in quartz and feldspar from the Saukhark Granite-Gneiss indicate that temperatures during recrystallisation were around $450-550{ }^{\circ} \mathrm{C}$. These P-T estimates suggest that most of the now exposed rocks in the Dadeldhura Group experienced prograde epidoteamphibolite facies metamorphism during early orogenic build up and thrusting of the Dadeldhura Nappe. A subsequent syntectonic retrograde phase is observed in the NDT zone as low temperature recrystallisation of quartz and feldspar in mylonitic rocks, and chlorite and quartz in chlorite-grade rocks holding relict kyanite. Retrograde trusting was also focused along a distinct "back thrusting" zone within the northern part of the group.
\end{abstract}

\section{INTRODUCTION}

The Dadeldhura Group constitutes a thrust sheet of metamorphic rocks situated in central Himalaya of Far Western Nepal (Fig. 1). These rocks are equivalent to the Bhimphedi Group of rocks in Central Nepal (Stöcklin and Bhattarai 1977; Upreti 1999) and a large part of the group includes the Lower Palaeozoic granites which are found all along the range (Le Fort and Rai 1999). The rocks of the Dadeldhura Group are posited some $100 \mathrm{~km}$ south of the Main Central Thrust zone. Studies in the Kumaon region of Indian Himalaya, just west of the Dadeldhura region, conclude that the root zone of the Lesser Himalayan Crystallines in this area is posited in a thrust sheet underlying the Main Central Thrust and Greater Himalayan rocks (Srivastava and Mitra 1994). However, such interpretations are not agreed on by all (e.g. DeCelles et al. 2000; Gehrels et al. 2006).

Present study focuses on the petrological, structural, and thermobarometric analyses of an N-S profile of the Dadeldhura Nappe (Fig. 2). Special focus has been given to the northern part of the group, on rocks in the vicinity of the North Dadeldhura Thrust (NDT). The rocks of the NDT zone together with the garnet-bearing rocks situated south of it are discussed in terms of petrography and microstructures. Garnet-biotite thermometry and Garnet-biotite-muscoviteplagioclase barometry are applied in these rocks. The Ordovician granite (Saukhark Granite-Gneiss) constituting a large part of the group is described with emphasis on recrystallisation textures in quartz and feldspar to reveal temperatures of recrystallisation.

\section{ROCK UNITS AND STRUCTURAL SETTING}

The Dadeldhura Group is situated in a synformal structure (Fig. 2) and can be subdivided into four major formations. Their rock types and mineralogy is presented in Table 1. The Mateligauda Formation has been renamed by the author and is equivalent to the Gaira Formation of Upreti (1990).

The NDT zone is defined by the base of the Mateligauda Formation (rock units 1 and 2). Unit 1 is composed of different metamorphic rocks that are sheared together occurring repeatedly (quartz-chlorite schist, mylonite and amphibolite). Continuing structurally up section and into rock unit 2 , these 


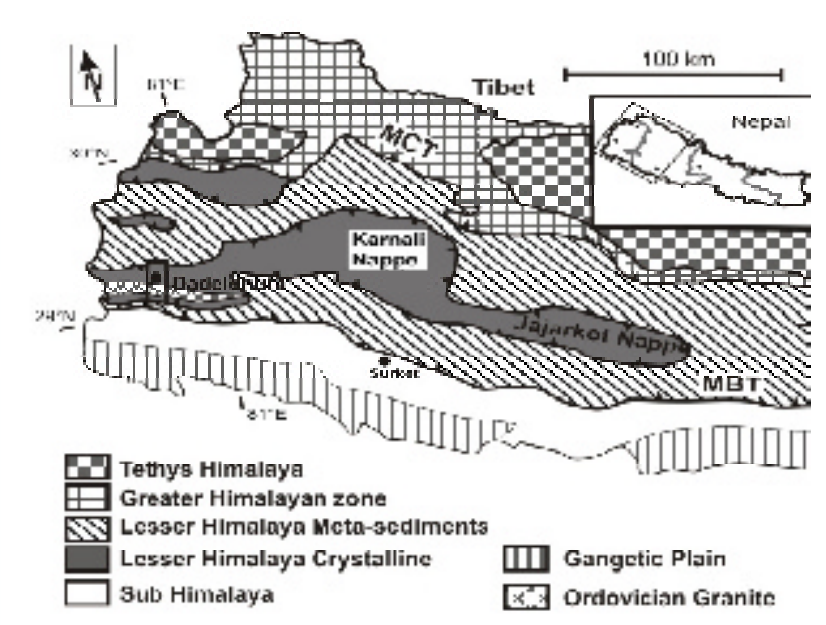

ligure 1. Author: 'lomas Namaa, Jens Konnerup-Madser Pjom Hngeskov \& I nlu Prasind Pandel

Fig. 1: Geologic map of western Nepal (after DeCelles et al. 1998; Upreti 1996, 1999; Valdiya 1980; Amatya and Jnawali 1994). The Dadeldhura Group comprises of a large crystalline nappe in the central Himalaya. The rectangle outlines the area where the group has been described, and also outline the study area. MFT= Main Frontal Thrust, MBT= Main Boundary Thrust, MCT= Main Central Thrust.

rocks grade into mylonites. Structurally above the mylonites, fine-grained banded gneisses with intercalated slices of mica schist dominate (rock unit 3). Throughout rock unit 3, mesoscale ductile deformation structures such as isoclinal folds and duplex systems are abundant. A zone dominated by quartzite beds (rock unit 4), ranging from a few centimetres up to 10 meter in thickness, separates the banded gneisses from the augen gneisses and highly sheared rocks of unit 5 . The augen gneisses of unit 5 have sharp contacts with finer grained highly strained rocks that have a mylonite appearance. The augen gneisses contain scattered large feldspar porphyroclasts (up to $10 \mathrm{~cm}$ ) a character similar to the Saukhark Granite-Gneiss. In units 3, 4, and 5 garnet porphyroblasts are present and many of them have sigmoidal inclusion trails. The structural configuration of the Mateligauda Formation is difficult to determine, but the unit are highly sheared and dip of the rocks indicate a synform (Fig. 2). However, correlation between the two limbs is not obvious and the presence of highly shared rocks in both its northern and southern limits suggests that thrust stacking has contributed to its configuration.

The next unit belonging to the Pokhara Phyllite lies to the south of the Mateligauda Formation. It consists of a grey-brown shiny phyllite situated in a synform. The northern part of the phyllite (the northern limb; Fig. 2) contains many ductile deformation textures and abundant quartz bodies. Just north of the hinge zone symmetric tight folds dominate, further north these are transformed into meso-scale isoclinal folds and ductile duplex systems, indicating an increase in deformation intensity toward the north. The northernmost part of the phyllite contains garnet porphyroblasts. About $15 \mathrm{~m}$ wide zone of chlorite schist marks the border of the Mateligauda Formation. South of the hinge zone the phyllite exhibits few deformation textures, but micro-scale zonal crenulation folds are present throughout. The contact zone of the Pokhara Phyllite and the Saukhark Granite-Gneiss is composed of phyllite, pegmatite, and augen gneiss that are sheared together.

The Saukhark Granite-Gneiss is a leucocratic granite, highly sheared in large parts of the body, and is characterised by scattered large tabular feldspar porphyroblasts (up to 10 $\mathrm{cm}$ ). It constitutes the major formation within the Dadeldhura Group. In the intensely deformed border regions the granite are transformed into augen gneiss (Fig. 2). In the southern part of the formation, a metasedimentary unit is intercalated into the Granite-Gneiss. Whole rock $\mathrm{Rb}-\mathrm{Sr}$ dating of the granite has revealed an age of $470 \pm 5.6 \mathrm{Ma}$ (Le Fort and Rai 1999). Zircon U-Pb dating from the Saukhark Granite-Gneiss have revealed a $\mathrm{U}-\mathrm{Pb}$ concordant age of $484 \pm 10 \mathrm{Ma}$ (Gehrels et al. 2006).

The Gaira Formation constitutes a mixture of different metamorphic rock types (Table 1). The northern part of the formation is mainly composed of muscovite-feldspar schist. A large part of the central formation is composed of phyllites and quartzites. Amphibolite and metasediments in the southern part of the formation might reasonably be correlated with the similar rocks types of the Budar Group, positioned south of the Dadeldhura Group (Bashyal 1981).

\section{PROGRADE KYANITE AND RETROGRADE RECRYSTALLISATION IN THE NDT ZONE}

Quartz-chlorite schist (Table 1) posited at the base of the NDT is composed of alternating layers of microcrystalline chlorite, quartz, and opaque minerals, which together define a $S_{1}$ foliation. Highly altered relicts of kyanite are aligned with the $S_{1}$ foliation and a $S_{2}$ zonal crenulation foliation overprints the $S_{1}$ foliation (Fig. 3). This suggests that the rocks experienced a prograde phase where kyanite crystallised during the development of a $\mathrm{S}_{1}$ foliation. A subsequent retrogression has overprinted the prograde assemblage, with chlorite as a major crystallising phase. The retrogression is syntectonic and occurred during the development of zonal crenulation foliation $\left(\mathrm{S}_{2}\right)$.

The NDT mylonites are granitic in composition (Table 1) and contain relicts of plagioclase feldspars. The relict feldspars are highly altered, micro-fractured, often broken and contain no core/mantle recrystallisation textures. Often the grains have a bulging morphology, suggesting that the relict grains have had a recrystallised mantle that was erased 


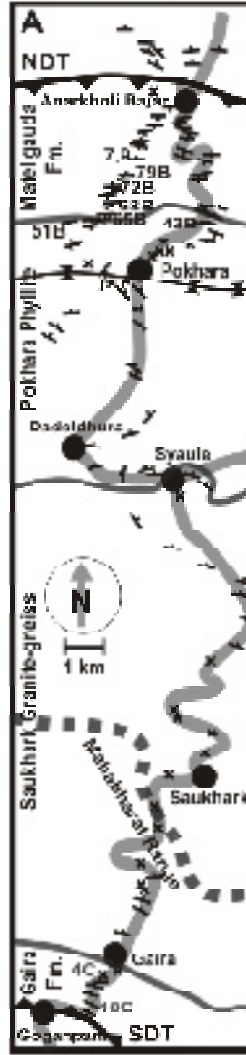

B
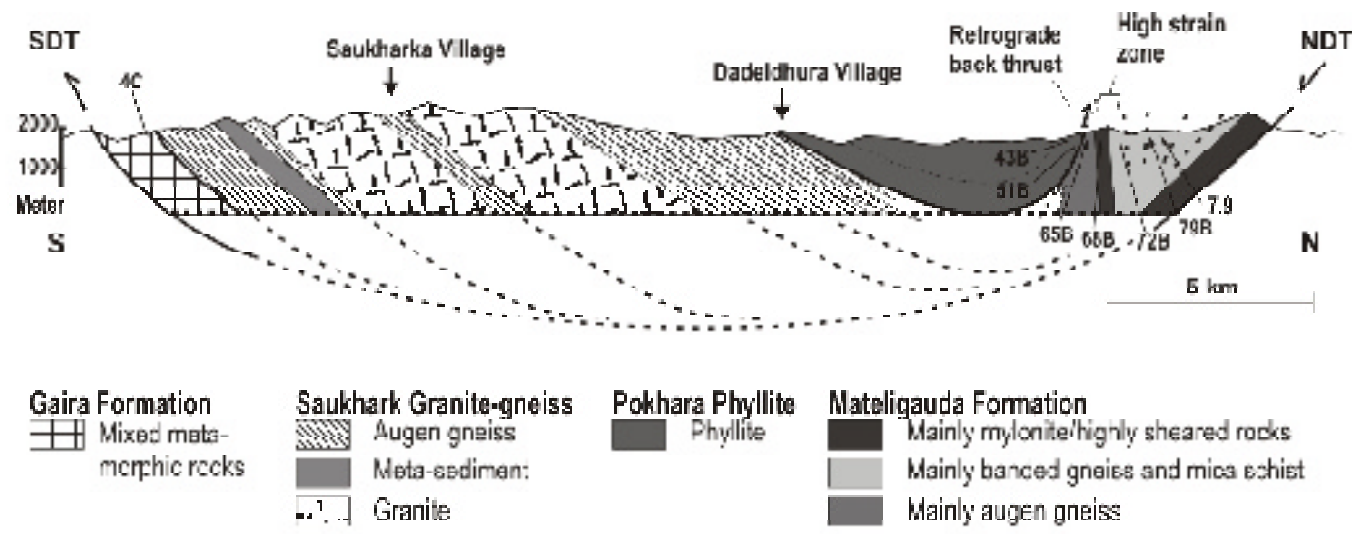

Pokhara Phyllite Mateligauda Formation

Phollitite

Mainly myloniteihignly sheared rodks
Mainly banced gneies and mica eshist

Mainly augen gneiss

... Proposed corfiguration cf toliaticn in napoe.

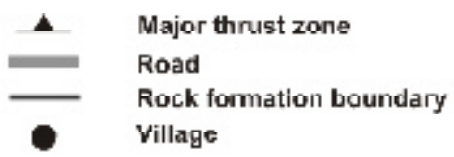

Fig. 2: A) Map of field area with locations and strike/dip indicators. B) North-south profile of the Dadeldhura Group from the field area. The southern part of the group is dominated by the Saukhark Granite-Gneiss; the rocks of the Pokhara Phyllite are situated in a synform. The structural configuration of the Mateligauda Formation is difficult to interpret with mylonite in its northern base and highly sheared rocks in the southern part it might represent a thrust stack. Correlation between the augen gneisses that delimits the Pokhara Phyllite (north - south) has not been established, but they have similar mineralogy and both contain scattered feldspar megacrysts. 4C, 43B, 51B, 65B, 68B, 72B, 79B, and 7.9 are localities where P-T estimates are obtained (Table 2). SDT=South Dadeldhura Thrust, NDT= North Dadeldhura Thrust.

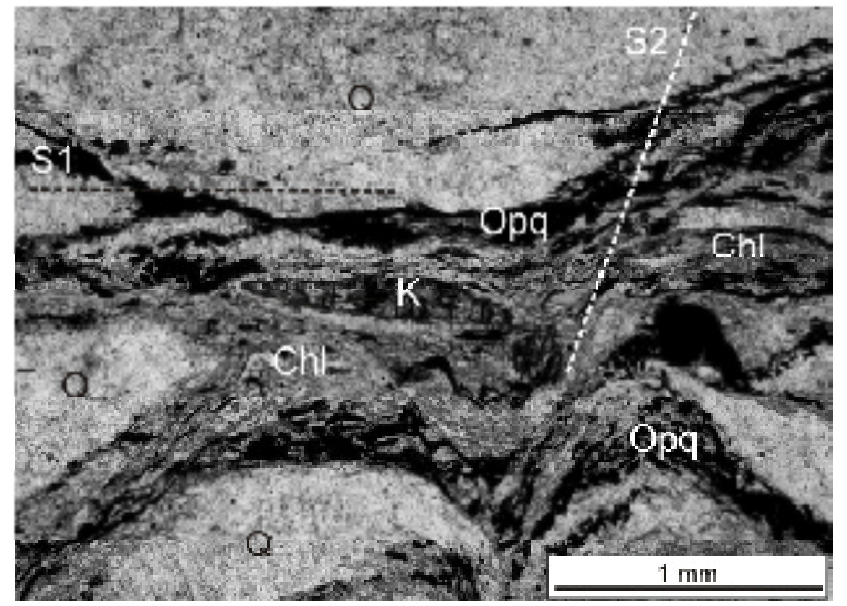

Fig. 3: Relict kyanite in a quartz-chlorite schist. Kyanite in the rock is rather crumble and is aligned with the $S 1$ foliation. A later deformation event has folded S1 and developed a S2 crenulation foliation defined by limbs of F2 folds. $\mathrm{Chl}=$ chlorite; $\mathrm{K}$ = kyanite; $\mathrm{Opq}=$ opaque phases; $\mathrm{Q}=$ quartz.

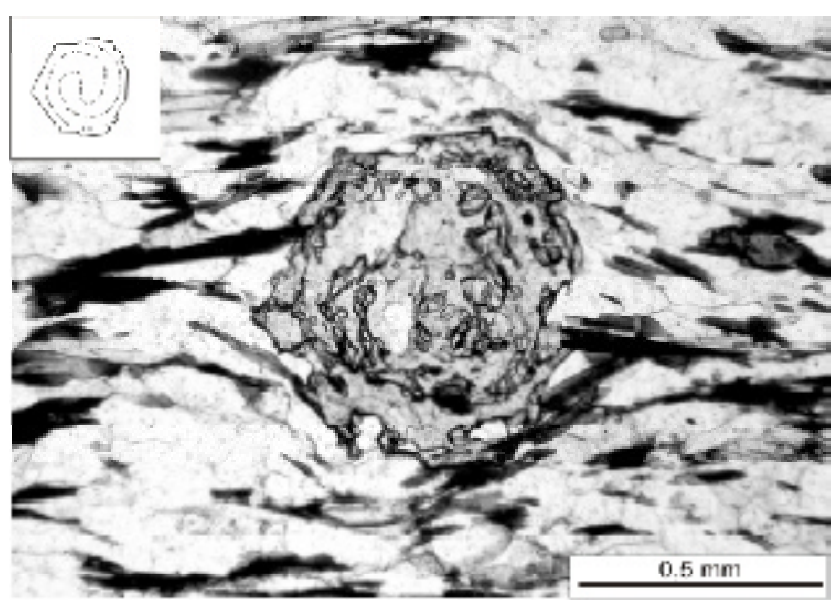

Fig. 4: Garnet with sigmoidal inclusion trails (68B, Fig. 2). The trails are rotated by 270 degrees indicating the growth in a shear zone. The garnet is situated in Unit 5 of the Mateligauda Formation and is associated with mylonites. 
Table 1: Rock type and mineralogy from the Dadeldhura Group. An = anorthite, $b t=$ biotite, ca $=$ calcite, chl = chlorite, ep

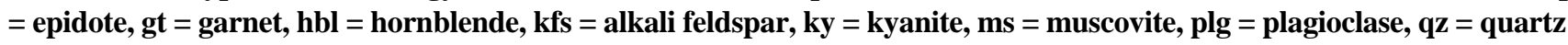

\begin{tabular}{|c|c|c|c|c|}
\hline Rock unit & Rock type & Prograde phases & Relict phases & Rock unit thickness \\
\hline & \multicolumn{2}{|c|}{ North Dadeldhura Thrust } & & \\
\hline \multicolumn{5}{|c|}{\begin{tabular}{|l|l|} 
Mateligauda Formation & \\
\end{tabular}} \\
\hline \multirow{3}{*}{1} & Quartz-chlorite schist & qz, chl, opaque phases & ky & \multirow{3}{*}{$250 \mathrm{~m}$} \\
\hline & Amphibolite & qz, plg (An3), bt, Hbl, ep & plg & \\
\hline & Mylonite & $\mathrm{qz}, \mathrm{plg}, \mathrm{kfs}, \mathrm{bt}, \mathrm{ms}, \mathrm{ep}$ & plg & \\
\hline 2 & Mylonite & $\mathrm{qz}, \mathrm{plg}(\mathrm{An} 4), \mathrm{kfs}, \mathrm{bt}, \mathrm{ms}, \mathrm{ep}$ & plg & $600 \mathrm{~m}$ \\
\hline \multirow{3}{*}{3} & Banded Gneiss & $\mathrm{qz}, \mathrm{plg}(\mathrm{An} 27), \mathrm{bt}, \mathrm{ms}, \pm \mathrm{ep}, \pm \mathrm{gt}$ & plg & \multirow{3}{*}{$1700 \mathrm{~m}$} \\
\hline & Mica schist & $\mathrm{qz}, \mathrm{bt}, \mathrm{ms}$ & & \\
\hline & Augen gneiss & $\mathrm{qz}, \mathrm{plg}(\mathrm{An} 24), \mathrm{kfs}, \mathrm{bt}, \mathrm{ms}, \mathrm{ep}, \mathrm{gr}$ & $\mathrm{plg}, \mathrm{kfs}$ & \\
\hline \multirow{2}{*}{4} & Mica schist & $\mathrm{qz}, \mathrm{plg}, \mathrm{kfs}, \mathrm{bt}, \mathrm{ms}, \mathrm{ep}, \pm \mathrm{ca}, \pm \mathrm{gt}$ & & \multirow{2}{*}{$450 \mathrm{~m}$} \\
\hline & Quartzite & $\mathrm{qz}, \mathrm{bt}, \mathrm{ms}$ & & \\
\hline \multirow{2}{*}{5} & Mylonite & $\mathrm{qz}, \mathrm{plg}(\mathrm{An} 16), \mathrm{kfs}, \mathrm{bt}, \mathrm{ms}, \pm \mathrm{gt}$ & plg, kfs & \multirow{2}{*}{$1000 \mathrm{~m}$} \\
\hline & Augen gneiss & $\mathrm{qz}, \mathrm{plg}(\mathrm{An} 2-13), \mathrm{kfs}, \mathrm{bt}, \mathrm{ms}, \mathrm{ep}, \mathrm{gt}$ & plg, kfs & \\
\hline \multicolumn{5}{|c|}{ Pokhara Phyllite } \\
\hline 1 & Quartz-chlorite schist & $\mathrm{qz}, \mathrm{plg}(\mathrm{An} 12-14), \mathrm{chl}, \mathrm{ms}$ & & $15 \mathrm{~m}$ \\
\hline 2 & Phyllite & $\mathrm{qz}, \mathrm{plg}(\mathrm{An} 13-17), \mathrm{bt}, \mathrm{ms}, \pm \mathrm{gt}$ & & $3200 \mathrm{~m}$ \\
\hline \multicolumn{5}{|c|}{ Saukhark Granite-gneiss } \\
\hline \multirow{2}{*}{1} & Granite & $\mathrm{qz}, \mathrm{plg}, \mathrm{kfs}, \mathrm{bt}, \mathrm{ms} \pm \mathrm{bt}$ & & \multirow{2}{*}{$7200 \mathrm{~m}$} \\
\hline & Augen gneiss & $\mathrm{qz}, \mathrm{plg}(\mathrm{An} 5-17), \mathrm{kfs}, \mathrm{bt}, \mathrm{ms}$ & plg, kfs & \\
\hline 2 & Meta-sediment & $\mathrm{qz}, \mathrm{bt}, \mathrm{ms}$, opaque phases & & $950 \mathrm{~m}$ \\
\hline 3 & Augen gneiss & $\mathrm{qz}, \mathrm{plg}, \mathrm{kfs}, \mathrm{bt}, \mathrm{ms}$ & plg, kfs & $1350 \mathrm{~m}$ \\
\hline \multicolumn{5}{|c|}{ Gaira Formation } \\
\hline 1 & Muscovite-feldspar schist & $\mathrm{qz}, \mathrm{plg}(\mathrm{An} 16), \mathrm{bt}, \mathrm{ms}, \mathrm{gt}$ & plg, kfs & $475 \mathrm{~m}$ \\
\hline 2 & Bedded quartzite-phyllite & $\mathrm{qz}, \mathrm{plg}, \mathrm{bt}, \mathrm{ms}$ & & $400 \mathrm{~m}$ \\
\hline 3 & Augen gneiss & $\mathrm{qz}, \mathrm{plg}, \mathrm{kfs}, \mathrm{bt}, \mathrm{ms}$ & plg, kfs & $200 \mathrm{~m}$ \\
\hline \multirow{2}{*}{4} & Bedded quartzite-phyllite & $\mathrm{qz}, \mathrm{plg}, \mathrm{bt}, \mathrm{ms}$ & & \multirow{2}{*}{$600 \mathrm{~m}$} \\
\hline & Muscovite-feldspar schist & $\mathrm{qz}, \mathrm{plg}(\mathrm{An} 11), \mathrm{bt}, \mathrm{ms}, \mathrm{gt}$ & & \\
\hline \multirow{3}{*}{5} & Pegmatite & $\mathrm{qz}, \mathrm{plg}, \mathrm{kfs}, \mathrm{bt}, \mathrm{ms}$ & & \multirow{2}{*}{$200 \mathrm{~m}$} \\
\hline & Amphibolite & qz, plg, bt, hbl, ep & & \\
\hline & \multicolumn{2}{|c|}{ South Dadeldhura Thrust } & & \\
\hline
\end{tabular}

during later deformation. The rigid behaviour of the feldspar augens suggests low-temperature conditions during the latest thrusting event. Quartz has undergone ductile deformation during the mylonitisation and recrystallised quartz fills fractures in the relict feldspars and surrounds the grains. The relative textures of quartz and feldspar indicate that temperatures during the late stages of mylonitisation were around $300-400{ }^{\circ} \mathrm{C}$ (Passchier and Trouw 1998, p. 52).

\section{GARNET-BEARING ROCKS AND A HIGH STRAIN ZONE SOUTH OF THE NDT ZONE}

Garnet-bearing rocks occur in about $2 \mathrm{~km}$ wide zone some 2 to $4 \mathrm{~km}$ structurally above the basal part of the NDT. The garnet zone covers the southern gneissic, schistose, and mylonitic rocks of the Mateligauda Formation (rock unit 3, 4, and 5) and continues into the northern part of Pokhara Phyllite. In the Mateligauda Formation, many garnets show sigmoidal inclusion trails indicating growth during shearing. In the Pokhara Phyllite, the garnets display straight or slightly curved inclusion trails indicating growth in an inter-tectonic environment or during folding of the rocks. In all examined garnets the internal foliations are discontinuous with the external foliation in the rocks.

The garnet in Fig. 4 is from a gneissic rock situated within Unit 5 of the Mateligauda Formation. The sigmoidal inclusion trail is rotated $270^{\circ}$, which demonstrate that the garnet has grown during shearing. This rock is associated with highly sheared mylonite like rocks and augen gneisses. It is to be noted that this mylonite zone is situated some $2-3 \mathrm{~km}$ structurally above and south of the mylonites of the NDT zone and separated from it by banded gneisses, schists, and metasedimentary rocks. It is therefore proposed that this high-strain zone reflects a thrust stacking event that occurred during the prograde metamorphism.

\section{RETROGRADE BACK THRUST}

The contact between the Mateligauda Formation and the Pokhara Phyllite is exposed at one locality. At this location, about $15 \mathrm{~m}$ wide zone of quartz-chlorite schist defines the contact region (Table 1, Fig. 2). The rock contains $\mathrm{S}-\mathrm{C}$ shear bands defined by chlorite and to a minor degree 
Table 2: Mineral chemistry used for thermobarometric calculations. $X=$ mole fraction; alm = almandine; prp = pyrope; sps

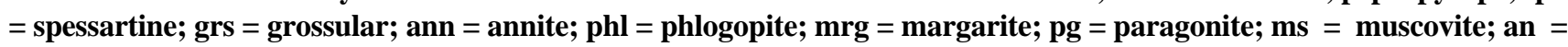
anorthite; $\mathbf{a b}=$ albite; or = orthoclase; GARB = garnet-biotite thermometry; GMBP = garnet-muscovite-biotite-plagioclase barometry

\begin{tabular}{|c|c|c|c|c|c|c|c|c|c|c|c|c|c|c|c|c|c|}
\hline Locality & Analysis & \multicolumn{4}{|c|}{ Garnet } & \multicolumn{2}{|c|}{ Biotite } & \multicolumn{3}{|c|}{ Muscovite } & \multicolumn{3}{|c|}{ Plagioclase } & \multirow[b]{2}{*}{ GARB } & \multirow[b]{2}{*}{ GMBP } & \multirow[b]{2}{*}{$\mathrm{P}$ (kbar) } & \multirow[b]{2}{*}{$\mathrm{T}\left({ }^{\circ} \mathrm{C}\right)$} \\
\hline \multicolumn{2}{|c|}{ Mateligauda Fm. } & Xalm & Xprp & Xsps & Xgrs & Xann & $\mathrm{Xphl}$ & Xmrg & Xpg & $\mathrm{Xms}$ & Xan & $\mathrm{Xab}$ & Xor & & & & \\
\hline 7.9 & 1 & 0.798 & 0.139 & 0.009 & 0.053 & 0.433 & 0.567 & 0.000 & 0.222 & 0.778 & 0.160 & 0.838 & 0.002 & + & + & 7.2 & 481 \\
\hline 7.9 & 2 & 0.813 & 0.130 & 0.010 & 0.024 & 0.455 & 0.545 & 0.002 & 0.166 & 0.832 & 0.160 & 0.836 & 0.004 & + & + & 5.6 & 540 \\
\hline 7.9 & 3 & 0.815 & 0.150 & 0.009 & 0.025 & 0.438 & 0.562 & & & & & & & + & & & 514 \\
\hline $79 \mathrm{~B}$ & 1 & 0.551 & 0.038 & 0.079 & 0.333 & 0.607 & 0.393 & 0.003 & 0.038 & 0.959 & 0.255 & 0.734 & 0.012 & + & + & 8.2 & 501 \\
\hline $79 \mathrm{~B}$ & 2 & 0.540 & 0.039 & 0.086 & 0.335 & 0.605 & 0.395 & & & & & & & + & & & 510 \\
\hline $79 \mathrm{~B}$ & 3 & 0.550 & 0.039 & 0.085 & 0.326 & 0.618 & 0.382 & 0.004 & 0.044 & 0.952 & 0.242 & 0.740 & 0.018 & + & + & 8.7 & 529 \\
\hline $72 B$ & 1 & 0.465 & 0.050 & 0.171 & 0.315 & 0.516 & 0.484 & & & & & & & + & & & 456 \\
\hline $72 B$ & 2 & 0.468 & 0.051 & 0.163 & 0.318 & 0.510 & 0.490 & & & & & & & + & & & 452 \\
\hline $72 B$ & 3 & 0.483 & 0.054 & 0.145 & 0.318 & 0.513 & 0.487 & 0.000 & 0.037 & 0.963 & 0.220 & 0.767 & 0.012 & + & + & 8.9 & 469 \\
\hline $68 \mathrm{~B}$ & 1 & 0.517 & 0.026 & 0.123 & 0.335 & 0.661 & 0.339 & 0.000 & 0.032 & 0.968 & 0.169 & 0.818 & 0.013 & + & + & 9.0 & 505 \\
\hline $68 \mathrm{~B}$ & 2 & 0.508 & 0.024 & 0.130 & 0.338 & 0.662 & 0.338 & 0.000 & 0.033 & 0.967 & 0.153 & 0.834 & 0.013 & + & + & 9.1 & 493 \\
\hline $65 \mathrm{~B}$ & 2 & 0.414 & 0.034 & 0.151 & 0.401 & 0.481 & 0.519 & 0.000 & 0.035 & 0.965 & 0.198 & 0.792 & 0.009 & + & + & 7.8 & 335 \\
\hline \multicolumn{18}{|c|}{ Pokhara Phyllite } \\
\hline $51 \mathrm{~B}$ & 1 & 0.700 & 0.094 & 0.034 & 0.173 & 0.590 & 0.410 & & & & & & & + & & & 699 \\
\hline $51 \mathrm{~B}$ & 2 & 0.689 & 0.087 & 0.046 & 0.178 & 0.580 & 0.420 & & & & & & & + & & & 658 \\
\hline $51 \mathrm{~B}$ & 3 & 0.700 & 0.089 & 0.037 & 0.174 & 0.580 & 0.420 & 0.000 & 0.126 & 0.874 & 0.168 & 0.828 & 0.004 & + & + & 11.1 & 679 \\
\hline $43 \mathrm{~B}$ & 1 & 0.793 & 0.108 & 0.009 & 0.090 & 0.453 & 0.547 & & & & & & & + & & & 461 \\
\hline \multicolumn{18}{|c|}{ Gaira Formation } \\
\hline $4 \mathrm{C}$ & 1 & 0.781 & 0.161 & 0.017 & 0.041 & 0.465 & 0.535 & & & & & & & + & & & 589 \\
\hline $4 \mathrm{C}$ & 2 & 0.779 & 0.148 & 0.027 & 0.046 & 0.439 & 0.561 & & & & & & & + & & & 523 \\
\hline $4 \mathrm{C}$ & 3 & 0.787 & 0.143 & 0.025 & 0.046 & 0.457 & 0.543 & 0.004 & 0.283 & 0.712 & 0.159 & 0.837 & 0.004 & + & + & 6.9 & 541 \\
\hline
\end{tabular}

by biotite. The shear sense of the S-C fabric indicates that the zone has been active as a back thrust with top-to-thenorth-directed shearing. The zone is situated within garnetgrade rocks and as such represents a retrograde thrust zone.

\section{RECRYSTALLISATION IN THE SAUKHARK GRANITE-GNEISS}

Deformation and recrystallisation within the Saukhark granite-gneiss is focused along the margins of the granitic body. These zones are dominated by augen gneisses with well- developed schistose textures. Cleavage domains are composed mainly of biotite with muscovite as a minor phase. The microlithons are composed of either recrystallised quartz or aggregates of recrystallised feldspars, quartz and muscovite. Feldspar augens are abundant, displaying coremantle textures and are winged. The recrystallised mantles are thin, constituting only a narrow rim of the grains. The wings of the feldspars are long and narrow indicating a high degree of shear strain. Quartz is only present as a recrystallised assemblage. The relation of the recrystallisation textures in quartz and feldspar indicate that the temperature during recrystallisation was around $450-550{ }^{\circ} \mathrm{C}$ (Passchier and Trouw 1998, p. 52). In the zone of granite, where the original granitic appearance is intact in the hand specimen, recrystallisation textures are abundant under the microscope, and both quartz and feldspar occur as relict phases with core-mantle textures.

\section{GARNET-BEARING ROCKS OF THE GAIRA FORMATION}

Two garnet bearing rocks were mapped in the Gaira Formation. In the northern part of the formation, a garnetmuscovite schist display two generations of garnets that occur as larger and smaller grains. The larger grains possess a core, a compact inner mantle, and an inclusion-rich outer mantle, whereas the smaller grains are inclusion-rich without core-mantle relations and textural similar to the rims of the larger grains. In the southern part of the formation, a muscovite-feldspar schist contains garnet porphyroblasts that are inclusion-rich without core-mantle relations.

\section{MINERAL CHEMISTRY OF GARNETS}

Mineral chemistry was analysed by the JEOL JXA-8200 Superprobe at the Geological Institute of Copenhagen University. Profiles of garnets were constructed for all grains used for thermobarometric calculations. Fig. 5 displays three different zoning profiles from garnets in the northern zone (Fig 5 A, B and C) and from one in southern zone (fig 5D). Rim analyses used for geothermobarometry are listed in Table 2.

\section{The northern garnet zone}

Generally, the zoning profiles from garnets in this zone (Fig. 2) display growth zoning towards the south, and 

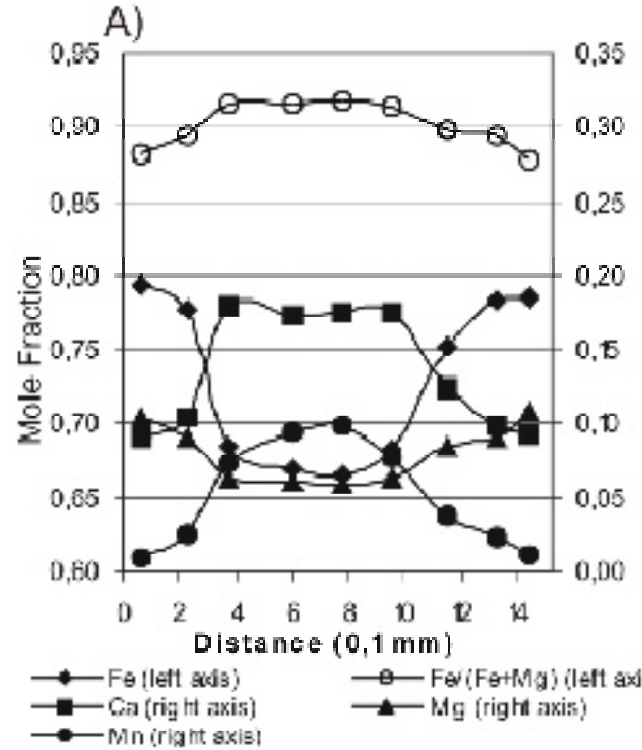

C)

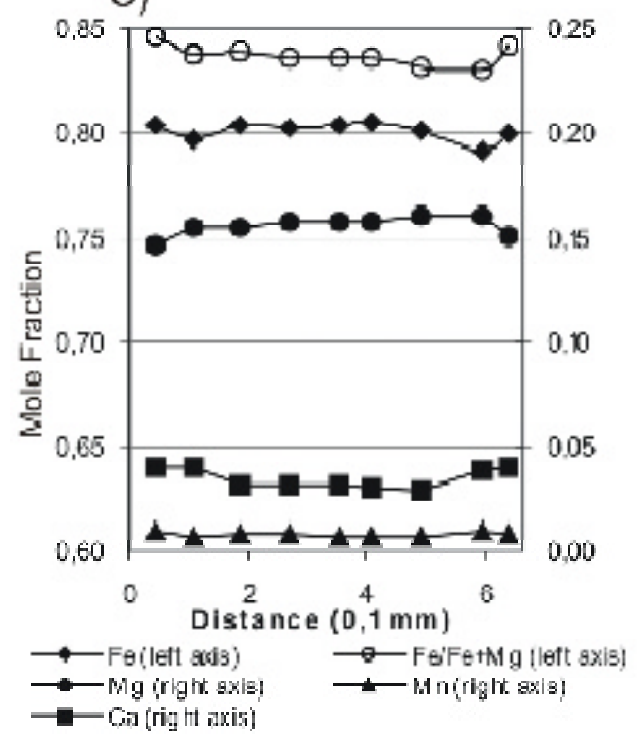

B)

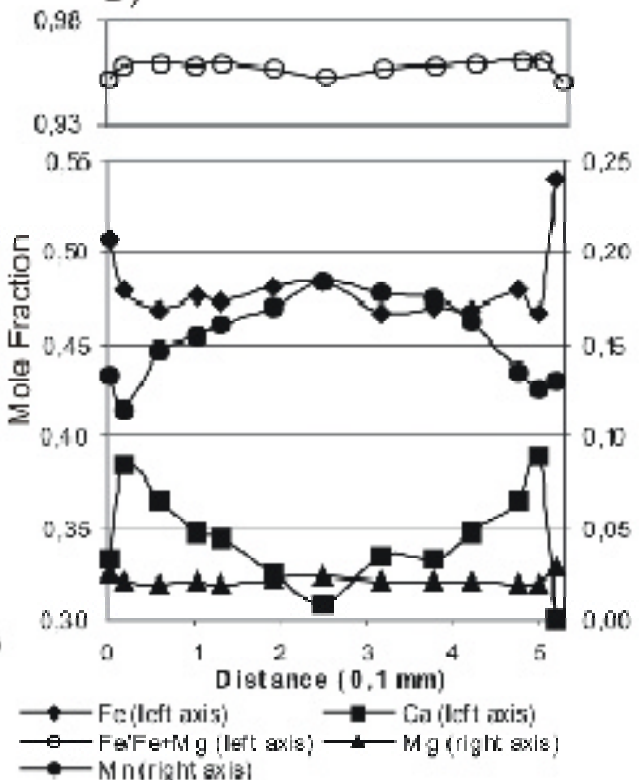

D)

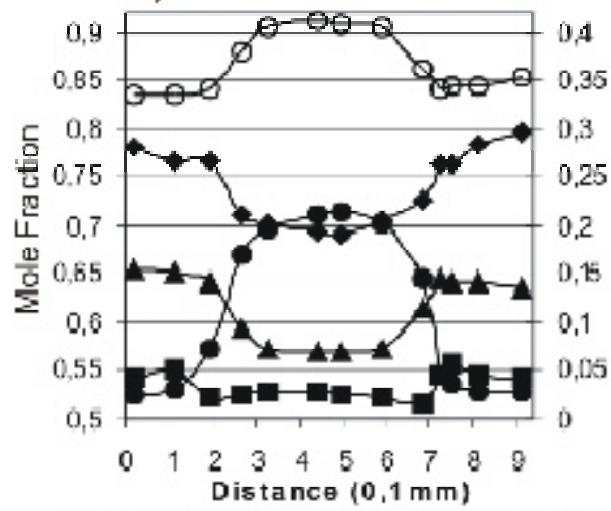

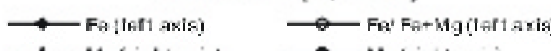

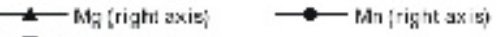

Fig. 5: Garnet zoning, rim-core-rim profiles. A) Growth zoning from a euhedral garnet in the Pokhara Phyllite (43B). B) Zoning from a spiral garnet in the Mateligauda $\mathrm{Fm}$. Mn decreases from core to rim and probably represents a growth zoning trend (68B). C) Anhedral garnet with a flat zoning porfile indicating diffusion zoning (7.9). D) Growth zoning combined with a flat rim profile $(4 \mathrm{C})$.

diffusion zoning towards the north as exemplified in Figs. 5A-C. In the Pokhara Phyllite, garnets are Fe-rich $\left(0.6<\mathrm{X}_{\mathrm{Fe}}\right.$ $>0.8$ ) with zoning profiles where $\mathrm{Fe}, \mathrm{Mg}$ content increases and $\mathrm{Mn}, \mathrm{Ca}$ content decrease from core to rim (growth zoning) (Fig. 5A). In the Mateligauda Formation, the garnets are also almandine-rich $\left(0.4<\mathrm{X}_{\mathrm{Fe}}>0.85\right)$ but with a larger difference in garnet chemistry from rock to rock and with diverse zoning patterns, generally with homogenised chemistry toward the north. The profile in Fig. 5B is of a spiral garnet from the southern part of the Mateligauda Formation. It is almandinerich $\left(0.46<\mathrm{X}_{\mathrm{Fe}}>0.55\right)$, its $\mathrm{Mn}$ content decreases from core to rim, $\mathrm{Ca}$ increases, and $\mathrm{Fe}, \mathrm{Mg}$ contents are constant. In the rim regions, the patterns are disturbed. The decreasing Mn content probably reflects a growth zoning pattern, which later was modified by diffusion. The garnet in Fig. 5C is from the northern part of the garnet zone. It has a high Fe content $\left(\mathrm{X}_{\mathrm{Fe}} \sim 0.8\right)$ and a rather homogenised chemistry which suggest diffusion zoning. This homogenisation of the garnet 


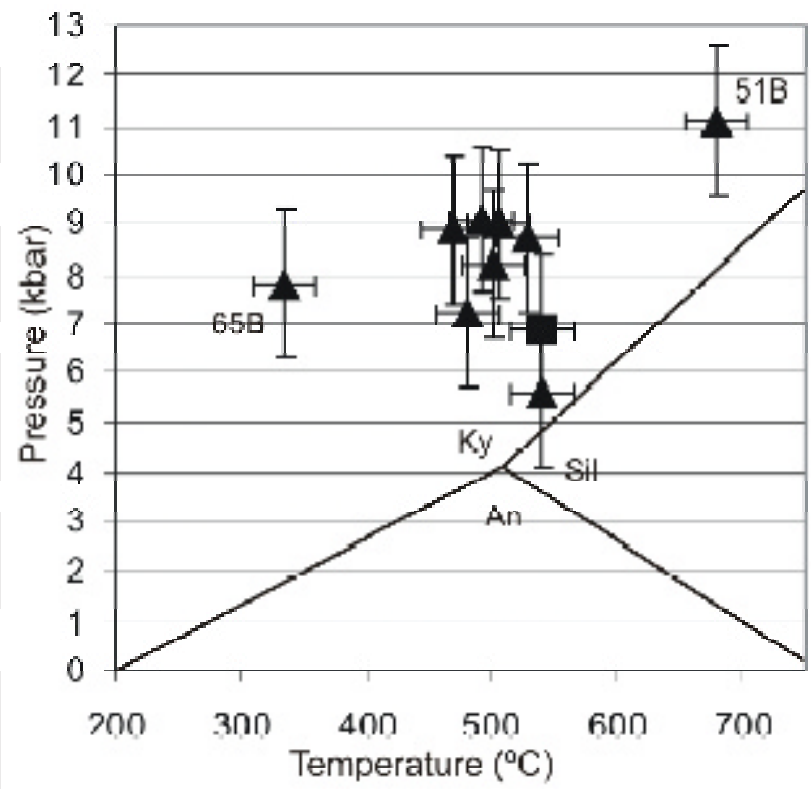

Fig. 6: P-T diagram of rocks from the Dadeldhura Group. Stability fields of the aluminium silicate phases are shown in the figure. $\mathrm{Ky}=$ kyanite; $\mathrm{Sil}=$ Sillimanite; $\mathrm{An}=$ Andalusite. Triangles are from the northern garnet zone, squares are from the southern garnet zone. 51B and 65B relate to locality number (Fig. 2).

chemistry might suggest that the rocks were heated to $650^{\circ} \mathrm{C}$ or above for an extended period of time (Tracy 1982).

\section{The southern garnet zone}

In the Gaira Formation, garnet from garnet-muscovite schist were analysed (Fig. 2). The rock contains spectacular almandine-rich garnets. The core and inner mantle show growth zoning, with bell shaped Mn profiles while the outer mantle, constituting the skeletal parts of the grain, show flat profile.

\section{THERMOBAROMETRY}

Temperature determinations are based on garnet-biotite cation exchange reaction (Holdway et al. 1997) and pressure determinations are based on the equilibrium reaction between garnet, muscovite, plagioclase and biotite (Ghent and Stout 1981). The $P-T$ estimates are based on near-rim analysis. The garnet-biotite pairs used for temperature determinations were in contact where as the muscovite and plagioclase grains used for pressure estimates were taken as close to these pairs as found. $P-T$ data with relevant near-rim analysis are presented in Table 2 and the locations of the analysed samples are show on Fig. 2 . The $P-T$ points cluster in a temperature range from $\sim 440-550{ }^{\circ} \mathrm{C}$ and a pressure range from 6.5 to 9 kbar (Fig. 6). The uncertainty bars on Fig. 6 are minimum values of the two models. Note that the $P-T$ estimate from the Gaira Formation is similar to the $P-T$ estimates from the northern garnet zone. With a pressure gradient of $0.27 \mathrm{kbar} / \mathrm{km}$, the pressure estimates correlate with a depth of $24-33 \mathrm{~km}$.

Two $P-T$ estimates (rock 51B and 65B) very distinctively fall out from the others. These two samples are situated on each side of the "back thrust" separating the Mateligauda Formation from the Pokhara Phyllite. It is difficult to see a geological reason for the large deviates, and the most likely explanation is that they represent a non-equilibrium system. The obtained pressure estimates have a large spread (2.5 kbar or about $9 \mathrm{~km}$ ) which could either reflect the proposed thrust stacking or some of the pressure estimates represent non-equilibrium systems.

\section{DISCUSSION}

The prograde metamorphism in the Dadeldhura thrust sheet are discussed by: 1) relict kyanite in chlorite-grade rocks from the NDT zone, 2) thermobarometry and microstructures from garnet bearing rocks and, 3) recrystallisation textures in quartz and feldspar in the Saukhark Granite-Gneiss. The rocks of the NDT zone experienced a protracted thrusting history with a prograde kyanite-grade episode followed by a retrograde chloritegrade episode. Structurally above the NDT, thermobarometry from garnet bearing rocks reveal re-equilibration temperatures about $440-550^{\circ} \mathrm{C}$ and pressure about $6.5-9 \mathrm{kbar}$. In the Saukhark Granite-Gneiss similar temperatures (440$550{ }^{\circ} \mathrm{C}$ ) are obtained by analysing recrystallisation textures of quartz and feldspar. These evidences indicate that thrusting of the Dadeldhura Nappe occurred during kyanitegarnet-grade metamorphism and that during the prograde episode recrystallisation and/or neocrystallisation affected most of the now exposed rocks across the nappe. Garnet with spiral inclusions from the high-strain zone (Fig. 2) in the southern part of the Mateligauda Formation together with the abundance of ductile shear structures, e.g. isoclinal folds and duplex systems in the Mateligauda Formation, demonstrate that a major part of the formation has experienced a large degree of shearing during the prograde metamorphism. These evidences suggest that the rocks of the Mateligauda Formation represent a basal part of the nappe where thrust stacking occurred. Subsequent retrograde metamorphism is observed in: 1) the NDT zone as recrystallisation textures in quartz and feldspar in the granitic mylonites, 2) as retrograde (chlorite) overprinting of kyanite holding quartz-chlorite schist also in the NDT zone and 3) as a narrow chlorite-grade thrust within the crystalline nappe. In the NDT zone recrystallisation textures indicate that retrogression was syn-tectonic and occurred with temperatures around $300-400{ }^{\circ} \mathrm{C}$. A narrow retrograde thrust, with top the north directed thrusting, is present at the border between the Pokhara Phyllite. This indicates that continued trusting was contemporary with uplift and that the consequence of this was a focusing of the recrystallisation and shearing along the NDT and a narrow internal back thrust zone. 


\section{Tomas Naraa et al.}

It is noticed that augen gneisses with large porphyroclasts are observed in the Saukhark granite-gneiss and in the southern Unit 5 of the Mateligauda Formation. Their like appearance and similar mineralogy viewed together with the structural positions make it tempting to correlate the two gneisses.

\section{CONCLUSIONS}

Prograde metamorphism in the Dadeldhura Group are described by 1) recrystallisation textures in quartz and feldspar from the Saukhark granite-gneiss that indicate temperatures around $440-550{ }^{\circ} \mathrm{C}$ and 2 ) thermobarometry from garnet bearing rocks in the northern and southern part of the group, which gives temperatures from $450-550^{\circ} \mathrm{C}$ and pressures from 6.5-9.5 kbar. Spiral garnets and abundance of highly strained rocks in the Mateligauda Formation in the northern part of the group show that the lower $\sim 4 \mathrm{~km}$ of the group are highly sheared; which suggest that the configuration of these rocks was established by thrust stacking. Subsequent retrograde metamorphism and recrystallisation was focused along the NDT zone and a narrow back thrust zone with in the nappe.

\section{ACKNOWLEDGEMENT}

We would like to acknowledge the Central Department of Geology, Tribhuvan University, for support extended during the work in Nepal.

\section{REFERENCES}

Amatya, K. M. and Jnawali, B. M., 1994, Geological Map of Nepal. Department of Mines and Geology, Ministry of Industry, Commerce and Supplies, Kathmandu, Nepal.
Bashyal, R. P., 1981, Geology of the Dhangarhi-Dandeldhura road section and its regional significance. Jour. Nepal Geol. Soc., v. 1(1), pp. 15-28.

DeCelles, P. G., Gehrels, G. E., Quade, J., LaReau, B., and Spurlin, M., 2000, Tectonic Implications of U-Pb Zircon Ages of the Himalayan Orogenic Belt in Nepal. Science, v. 288, pp. 497-499.

Gehrels, G. E., DeCelles, P. G., Ojha, T. P., and Upreti, B. N., 2006, Geologic and U-Pb geochronologic evidence for early Paleozoiv tectonism in the Dadeldhura thrust sheet, far-west Nepal Himalaya. Jour. Asian Earth Science, v. 28, pp. 385-408.

Ghent, E.D. and Stout, M. Z., 1981, Geobarometry and Geothermometry of Plagioclase-Biotite-Garnet-Muscovite Assemblages. Contribution to Mineralogy and Petrology, v. 76, pp. 92-97.

Holdway, M. J., Mukhopadhyay, B., Dyar, M. D., Guidotti C. V., and Dutrow, B. L., 1997, Garnet-biotite geothermometry revised: New Margules parameters and a natural specimen data set from Maine. American Mineralogist, v. 82, pp. 582-595.

Le Fort, P. and Rai, S. M., 1999, Pre-Tertiary felsic magmatism of the Nepal Himalaya: recycling of continental crust. Jour. Asian Earth Science, v. 17, pp. 607-628.

Passchier, C. W. and Trouw, R. A. J., 1998, Microtectonics. Springer-Verlag Berlin Heidenberg.

Srivastava, P. and Mitra, G., 1994, Thrust geometries and deep structure of the outer and lesser Himalaya, Kumaon and Garhwal (India): Implications for evolution of the Himalayan fold and thrust belt. Tectonics, v. 13(1), pp. 89-109.

Tracy, R. J., 1982, Compositional zoning and inclusions in metamorphic minerals. In: Reviews in Mineralogy, 10. Characterization of metamorphism through mineral equilibria. (ed. Ferry, J. M), Mineralogical Soc. America, Washington DC., pp. 355-397.

Upreti, B. N., 1999, An overview of the strategraphy and tectonics of the Nepal Himalaya. Jour. Asian Earth Sci., v. 17, pp. 577-606.

Upreti, B. N., 1990, An outline Geology of Far Western Nepal. Jour. Himalayan Geology, v. 1, pp. 93-102. 